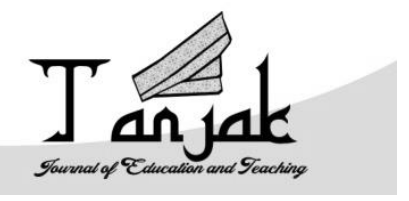

\author{
Tanjak: Journal of Education and Teaching \\ ISSN 2716-4098 (P) 2720-8966 (0) \\ Volume 2 Nomor 1, 2021
}

\title{
STUDENT'S ATTITUDE AND PERSONALITY TRAITS TOWARD ENGLISH LEARNING ACHIEVEMENTS
}

\author{
Meiriska Nirmala Dewi ${ }^{1 *}$ \\ ${ }^{1}$ Universitas Islam Negeri Sultan Syarif Kasim Riau, Pekanbaru, Riau, 28289, Indonesia.
}

DOI: https://doi.org/10.31629/ig.v2i1.134

\begin{abstract}
Abstrak
Ada beberapa fator yang dapat mempengaruhi prestasi siswa dalam belajar bahasa inggris. Factor tersebut bisa berasal dari internal and eksternal diri siswa. Penelitian ini focus pada factor internal yang dapat mempengaruhi prestasi belajar siswa, yaitu sikap dan kepribadian siswa. Beberapa teori yang berkaitan dengan focus kajian ditelaah untuk mengetahui apakah ada hubungan sikap dan kepribadian siswa terhadap prestasi belajar mereka. Berdasarkan beberapa teori, sikap siswa tercermin letika mereke bertingkah, berpikir, dan merespon terhadap suatu hal. Kepribadian siswa adalah sesuatu yang ada diadalm diri dan juga mempengaruhi prestasi belajar mereka. Seperti yang dikemukakan oleh Goldberg (2001) tentang pengaruh kepribadian pertisipan penelitian. Penelitian ini menggunakan kuesioner yang diadaptasi dari IPIP tentang kepribadian dan satu kuesioner tambahan tentang sikap. Jenis penelitian ini adalah peneltian korelasi yang menggunakan Analisa regresi sederhana dan ganda. Hasil penelitian ini menunjukkan adanya hubungan antara sikap dan kepribadian siswa terhadap prestasi mereka dalam belajar Bahasa inggris.
\end{abstract}

Kata kunci: sikap; kepribadian; prestasi.

\section{Abstract}

There are some factors that may influence students English learning achievements. They may be internal and external factors. This study focuses on internal factors of students which assumed affecting their English learning achievements; they are students' attitude and personality traits. To find out the influence of students' attitude and

Tanjak: Jounal of Education and Teaching, Vol. 2, No. 1, 2021 
personality traits towards their English learning achievement, some theories and previous related research have been carried out. Based on the theories, people' attitudes influence on how they behave, think, and respond to something. Besides, students' personality traits are also assumed has influence to their English learning achievements. Goldberg (2001) proposes International Personality Item Pool (IPIP) to assess partcipants' perception of personality traits. This study adopted questionnaires of IPIP about personality traits and provided another questionnaire about attitudes. Design of this study is a correlational research design which used simple and multiple regression analysis. The finding shows that there is significant influence of students' attitude and personality traits towards their English learning achievements.

Keywords: attitudes, personality traits, English achievements.

\section{Introduction}

In educational system, learning achievement determines the level of students' learning process system. Almost every aspect of everyday life of students is carried out in test forms such as doing exercises, homework, project papers, reports, and even final exams, thus, we can realize how important the role of achievement for students in educational world. There are many factors can influence the students' achievement in learning English. Naderi et al (2009) stated that academic achievement is strongly influenced by demographic and psychological factors. Though a series of variables influence the achievement level of students in general, those students' attitude and creativity factors could be used to predict their achievement. However, few studies had been conducted to see whether the influence of students of attitude and creativity toward their English achievement.

Besides attitude, personality traits can also influence during the teaching and learning English subject. In accordance with big five factors proposed by Goldberg (2001), Robert and Paul (1992), the students did not fulfill the criteria of having good personality traits in learning. These five factors are neuroticism, extraversion, openness, agreeableness, and conscientiousness. For example, in neuroticism factor, some students are prone to negative emotions such as anxiety, anger, hostility, resentment and depression. When they get difficulties in learning, they feel anxiety and do not want to find the way solve it. But this study focuses only on overall stdents' attitude and personality traits towards English learning achievements.

\section{Literature Review}

Achievement is obtained as a standard of learners' success in learning. It is determined with scores decided by the institutional of education itself. This achievement is given in the end of teaching and learning process based on students' performance during study, especially in the school; the achievement is given by the teachers. According to Payne (2003), an Achievement test provides evidence about a student's status or level of learning. They may deal with knowledge of facts and principles in complex and usually life like situations. In general, it can be concluded that achievement is the progress that the students make in their learning. Achievement can be measured with either standardized or teacher made tests. The test is used to describe performance in the subjects of the curriculum.

Meriam - Webster Collegiate Dictionary (2004) asserted that there are three definitions about achievement, they are: (1) Achievement is the act of achieving, accomplishment; (2) Achievement is the result gained by effort and a great or heroic deed; (3) Achievement is the quality and quantity of a

Tanjak: Jounal of Education and Teaching, Vol. 2, No. 1, 2021 http://ejournal.stainkepri.ac.id/index.php/tanjak 
students' work.

There are many factors affecting students' learning achievement. Factors that influence learning achievement can be divided into two general groups these are internal and external factors. It is supported by Suryabrata (1983), he stated that factors influencing students' learning achievement are factors that come from students' external and internal sides. In short, both students' external and internal factors can affect students' achievement.

Here the explanation about external and internal factors that can affect students' learning achievement: (1) Internal Factor; means that factors inside the students that influence them in learning English. There are two general groups in internal factor, namely; physiological factors and psychological factors.

Physiological factors. In physiological factors, there are two kinds of conditions, they are; general physiology condition and particular physiology condition. General physiology condition influences students learning process based on students' healthy condition. A student who is sick or has bad health condition has weak physic, so their sensory and motorist nerve become weak and they will be difficult to learn or study. Particular physiology condition that related to the function of five senses in learning process especially sight and hearing, and also another physical defect will disturb students' concentration in learning process. Psychological factors. Psychological factor is divided into two types; these are cognitive and non-cognitive variable. Cognitive variable consists of talent and intelligence. While, non-cognitive variables consist of; interest, motivation and students' maturity.

Another factor influence learning achievement is (2) External Factors. The external factor is learner subjects for example English because of the influence from outside. They need to learn English because there is English lesson at school.

Measuring achievement through test and assessment needs a well consideration. In formal education form, the teacher uses instruments in testing and assessing students' achievement. According to Salvador and Carmen (2001), there are two types shift of test and assessment in measuring achievement they are: (1) Validity shift from behavioral to cognitive, and (2) Psychometric shift from the application of the linear to item response model.

Pour (2015) stated that academic achievement is the main criterion for measuring education system in reaching to academic purposes. Achievement means the proficiency that students have in their learning process. It is an indicator that what students get in their learning. There is a kind of test to measure it, it is called achievement test. It indicates information that students have mastered in learning process. It is designed in the scores by test score or teachers' marks. It can be assumed that, academic achievement is the way to measure of education system in other to get some academic purposes. It is quality and quantity of student's activity.

According to Brown (2010), achievement test is the most frequent purpose for which a classroom teacher will use a test to measure learners' ability within the classroom lesson, unit, or even total curriculum. It is explained clearly that by knowing the level achievements of students will show the level of their overall abilities related to lesson, unit, or even total curriculum standard. Measuring achievement in academic purpose is applied by testing and assessing students' knowledge. The test and assessment are given by considering the instruments which are related to the material. The teacher can consider some test constructions in measuring the achievement of students. Then, there will be score of students' achievements as reflection for the students about how far their abilities are in English subject.

Tanjak: Jounal of Education and Teaching, Vol. 2, No. 1, 2021 
The word attitude has been a crucial component in measuring the students' learning achievement. In line with curriculum 2013 which proposes attitude as the main factor to consider students' affective score. It also determines criteria for students to pass minimum criteria of learning. According to Alkaff (2013), attitude plays an important role in second language learning as it determines to a large extent of the learners' behaviors, i.e., action taken to learn, or efforts exerted, during the learning process. Attitudes can be defined as the behavioral outcomes of perceptions. In other words, it means reactions or responses which based on individuals' feelings. According to Samadani and Ibnian (2015), attitudes can be explicit and implicit. Explicit attitudes are those that we are consciously aware of and that clearly influence our behaviors and beliefs. Implicit attitudes are unconscious but still have an effect on our beliefs and behaviors.

According to Chaihiranwattana and Nookua (nd), they said that proficiency in acquiring a second language may also be influenced by attitude. In other words, it can be said that attitude can guide the learners to achieve second language proficiency. It is also stated by Gajalakshmi (2013), he said that student's attitude is an integral part of learning and that it should, therefore become an essential component of second language learning pedagogy. It assumes that, attitude is one of the major factors which cannot be separated from learning process especially learning a second language. So, learner attitudes have an impact on the level of L2 proficiency achievement.

In the following, Abidin, Mohammadi and Alzwari (2012) explained the three aspects of attitude concept i.e., behavioral, cognitive, and emotional aspects.

Behavioral Aspect of Attitude. The behavioral aspect of attitude deals with the way one behaves and reacts in particular situations. In fact, the successful language learning enhances the learners to identify themselves with the native speakers of that language and acquire or adopt various aspects of behaviors which characterize the members of the target language community.

Cognitive Aspect of Attitude. This aspect of attitude involves the beliefs of the language learners about the knowledge that they receive and their understanding in the process of language learning. The cognitive attitude can be classified into four steps of connecting the previous knowledge and the new one, creating new knowledge, checking new knowledge, and applying the new knowledge in many situations.

Emotional Aspect of Attitude. Feng and Chen (2009) stated that, "Learning process is an emotional process. It means that, there are varieties of emotions which activating students' expression derived as the result of activities in learning process. It is affected by different emotional factors. The teacher and his students engage in various emotional activities in it and varied fruits of emotions are yield. Attitude can help the learners to express whether they like or dislike the objects or surrounding situations. It is agreed that the inner feelings and emotions of FL learners influence their perspectives and their attitudes towards the target language (Choy \& Troudi, 2006). In short, learning foreign language can be influenced by learners' feelings and emotions.

The role of students' attitude towards language learning achievements have been discussed in some articles. Attitude is focus on how individual thinks, acts, and behaves about a particular thing. According to Mensah et al (2013), attitude can also be formed which comes from someone's experiences. The experiences stimulate her/him to perform attitudes. It can be concluded that attitude is a response of students about something based on what they have experienced.

Tanjak: Jounal of Education and Teaching, Vol. 2, No. 1, 2021 http://ejournal.stainkepri.ac.id/index.php/tanjak 
In relating to language learning achievements, the role of attitude has particular impacts for the learners. Saidat (2010) stated that language attitudes of students have been considered in the previous 50 years because the development relation between the importance of language use and the nature of individuals. Moreover, Popham (2011) supported that the importance of attitudes in language learning. He stated that students' future behavior is influenced by three affective domains, they are attitudes, interests, and values. He also stated that three variables are important in language learning.

According Brown (2000), there are several studies about the effect of attitudes toward language learning. He came up with a conclusion that positive attitudes toward people, the native language group, and the target language group could enhance proficiency. It indicates that when students have positive attitude experience success, then the attitudes are reinforced. Besides, those with negative attitudes may fail to progress and become even more negative in their language learning attitudes. Then it gives impact to their language learning achievements.

Personality within learners is one of the factors determining their success in acquiring second language. Personality plays an important role in influencing learners' willingness in acquiring their second language. This idea is supported by numerous scholars who have conducted intensive research and even have written books about it.

According to Troike (2005), he states that there are three factors which influence learners in acquiring their second language acquisition, they are: linguistic, psychology and social context. In relating to this future research, our focus is only on psychology where personality takes place. Troike also mentioned that learners' diversity in acquiring a second language is also influenced by personality factor. Some other scholars also gave clear opinion about the existing of personality influence in second language learning achievement. Reported by Yan Zhang (2008), he quotes: "A number of theories hold that personality factors significantly influence the degree of success that individuals achieve in learning a second language (Gass \& Selinker, 1994) based on the assumption that some features of the learner's personality might encourage or inhibit second language learning (Cook, 1996)".

Goldberg (2001), Cherry (2013) reviewed five categories which are usually described as follows: (1) Extraversion; this trait includes characteristics such as excitability, sociability, talkativeness, assertiveness and high amounts of emotional expressiveness. (2) Agreeableness; this personality dimension includes attributes such as trust, altruism, kindness, affection, and other behaviors. (3) Conscientiousness; common features of this dimension include high levels of thoughtfulness, with good impulse control and goal-directed behaviors. Those high in conscientiousness tend to be organized and mindful of details. (4) Neuroticism; individuals high in this trait tend to experience emotional instability, anxiety, moodiness, irritability, and sadness. (5) Openness: This trait features, characteristics such as imagination and insight, and those high in this trait also tend to have a broad range of interests.

According to Dewaele (2013), personality traits of students develop their speaking confidence and willingness to communicate in English. It indicates one of big-five model personality of the students influence their confidence. It is the extraversion domain which include talkativeness indicator. In other words, the students with good extraversion of personality are motivated to speak confidently in learning, then it will influence their achievements in learning English as a foreign language.

Jafar (2014) reviewed MacIntyre and Charos research finding that global personality traits influenced second language learning motivation and willingness to communicate. It is supported by the

Tanjak: Jounal of Education and Teaching, Vol. 2, No. 1, 2021 http://ejournal.stainkepri.ac.id/index.php/tanjak 
mediation of intergroup attitude toward language, second language confidence and perceived communicative competence. It means that personality of students should be supported by motivation. In addition, MacIntyre et al stated that personality is central in setting the context for motivation to learn and communicate a second language.

In conclusion, some studies finding indicate there is influence of attitude and personality traits of learners towards their learning achievements. However, this current study focuses on overall students' attitude and personality traits influence towards their English learning achievements. Hopefully, students with good attitude and personality traits overall proved by high score of personality will get good English learning achievements.

\section{Research Method}

This study is a correlational research which use simple and multiple regression analysis of data. It was conducted on $18-22$ June 2020 at SMPN 3 Kuok. Total sample is 86 students. There were two independent variables; attitude and personality traits and one dependent variable; learning achievement.

The data was collecting by giving questionnaire about attitude and personality traits to be compared to the documented data, scores of students' English learning achievement. Each questionnaire consists of twenty-five items related to attitudes and personality traits of students. Attitude and personality traits questionnaires were adopted from AMBT and IPIP. They were developed and adjusted to the condition of students. Then the data collected was analyzed by using simple regression analysis of Pearson Product Moment and calculated by SPSS.

\section{Results and Discussion}

This study used simple regression analysis of data. Here is the descriptive statistic of data analysis.

Table 1. Descriptive Statistics

\begin{tabular}{|l|l|l|l|l|l|}
\hline & N & Mean & Std. Dvt & Min & Max \\
\hline ATTITUDE & 86 & 79.2000 & 8.16489 & 60.80 & 92.00 \\
$\begin{array}{l}\text { PERSONALITY } \\
\text { TRAITS }\end{array}$ & 86 & 81.3581 & 7.18175 & 62.40 & 94.40 \\
$\begin{array}{l}\text { ENGLISH } \\
\text { LEARNING } \\
\text { ACHIEVEMENT }\end{array}$ & 86 & 80.5233 & 4.96512 & 70.00 & 95.00 \\
\hline
\end{tabular}

Descent of the table 1. Numbers of respondents are 86 students in order to explain of mean score of students' attitudes is 79.2, which standard deviation is 8.1 , minimum score is 60.8 and maximum score is 92 . Continue of students' personality traits respondent are 86 which mean 81.3 , standard deviation is 7.1. minimum score is 62.4 and maximum score is 94.4. Then numbers of respondent are 86 students which mean 80.5, standard deviation 4.9, minimum score is 70 and maximum score is 95 .

Tanjak: Jounal of Education and Teaching, Vol. 2, No. 1, 2021 
Then, the data were analyzed by using simple regression analysis and calculated by using SPSS. The researcher used T-test to see the influence of independent variable individually to dependent variable.

Table 2. The Influence of attitudes towards English achievement

\begin{tabular}{|c|c|c|c|c|c|}
\hline \multirow[b]{2}{*}{ Model } & \multicolumn{2}{|c|}{$\begin{array}{l}\text { Unstandardized } \\
\text { Coefficients }\end{array}$} & \multirow{2}{*}{$\begin{array}{l}\text { Standardize } \\
\text { d } \\
\text { Coefficients } \\
\text { Beta }\end{array}$} & \multirow[t]{2}{*}{$T$} & \multirow[t]{2}{*}{ Sig. } \\
\hline & B & Std. Error & & & \\
\hline (Constant) & 40.029 & 3.971 & & 10.079 & .000 \\
\hline ATTITUDE & .314 & .123 & .517 & 2.551 & .013 \\
\hline $\begin{array}{l}\text { PERSONALITY } \\
\text { TRAITS }\end{array}$ & .192 & .140 & .278 & 1.671 & .014 \\
\hline
\end{tabular}

a. Dependent Variable: LEARNING ACHIEVEMENT

b. Independent variables: ATTITUDE AND PERSONALITY TRAITS

Based on the table, value of T for Students' Attitude is 2.551 and for Students' Personality Traits is 1.671. Degree of freedom $-\mathrm{df}(\mathrm{df}=\mathrm{n}-2-1)$ is 83 with error level $5 \%$, then $\mathrm{t}$ table is 1.663 . The result of $\mathrm{t}$ test of each variables; Ha1: There is a significant influence of students' attitude toward their English learning achievements. The result of T test shows that Students' Attitude value of $\mathrm{t}_{\text {count }} 2.551>$ $\mathrm{t}$ table 1.663 or sig $0.013<0.05$. Then it can be inferred that students' attitude has significant influence to their English learning achievements. In conclusion, Ha1 is accepted and Ho1 is rejected.

\section{Scatter Plot of Students' Attitude toward English Learning Achievement} Diagram 1

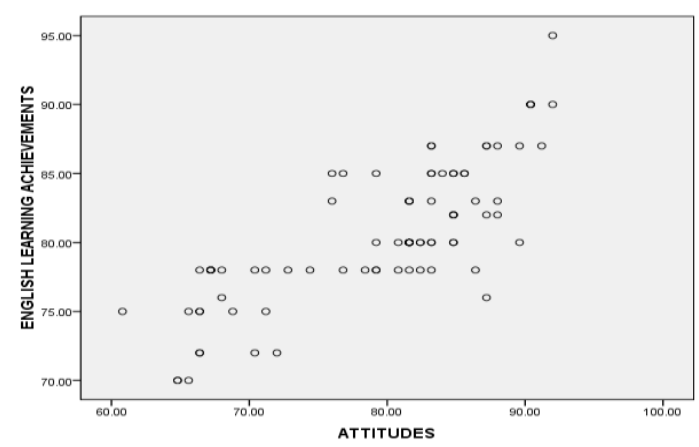

Diagram 1. Output scatter plot

Tanjak: Jounal of Education and Teaching, Vol. 2, No. 1, 2021 
Scatter diagram is used to see the correlation between two variables. Diagram above shows the correlation between students' attitudes and their English learning achievement. It strengthened the result of this study in proving Hypothesis 1 that there is significant influence of students' attitude towards their English learning achievement. Ha2: There is a significant influence of students' personality traits toward their English learning achievements. The result shows that for personality traits value of $t_{\text {count }} 1.671>t_{\text {table }} 1.663$ or sig is $0.014<0.005$. then it can be inferred that students' personality traits has significant influence to their English learning achievements. In conclusion, Ha2 is accepted and $\mathrm{Ho} 2$ is rejected.

\section{Scatter Plot of Students' Personality Traits towards English Learning Achievements} Diagram 2

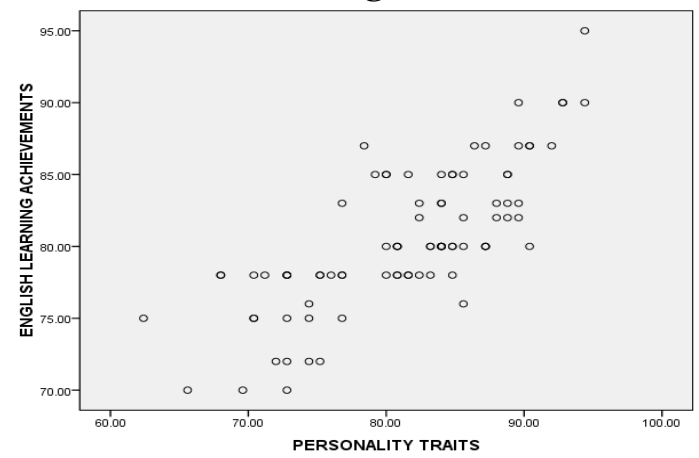

Diagram 2. Output scatter plot

Diagram above shows the correlation between students' personality traits and their English learning achievements. It proves the second hypothesis result test that there is significant influence of students' personality traits towards their English learning achievements.

\section{Conclusion}

There are two findings concluded by this research, the first finding indicated that there was positive influence of attitudes towards students' English achievement which proved by rho score 0.314 . By looking at the value of Sig. (2-tailed), it can be said that there is a significant influence of students' attitude toward their English achievement and also the value of simple regression, it was higher than $t_{\text {table }}$ by comparing it at significant level of $5 \%$.

The second finding, there is a positive influence of personality traits towards students' English achievement. The value of Sig. (2-tailed) was 0.192 , and total number of students was 86 . By looking at the value of Sig. (2-tailed), it can be said that there was a significant influence of students' personality traits towards their English achievement, and also the value of simple regression, it was higher than table by comparing it at significant level of $5 \%$.

Thus, according to research findings, it can be inferred that the better students' attitude, the higher score of students' English learning achievement would be, while the worse of students' attitude, the lower of students' English learning achievement would be. Then the students' English learning achievement was also influenced by personality traits. The better students' personality traits the higher students' English learning achievement, while the worse students' personality traits the lower score of

Tanjak: Jounal of Education and Teaching, Vol. 2, No. 1, 2021 
students' English learning achievement. So, in other words, when students have good attitudes as well as good personality traits and both cooperatively work during learning English, they were positively affected students' English learning achievements.

\section{Thankfulness}

The researcher would like to thank and appreciate everyone who helped her to complete this research so it can be finished in time.

\section{References}

AECT. (2001). Handbook of Research for Educational Communications and Technology. 1800 North Stonelake Drive, Suite 2. Bloomington, IN 47404. Retrieved from http://aect.org/edtech/ed1/ firstedition.asp.

Brown, H. D. (2000). Principles of Language Learning and Teaching. 4th ed. White Plains, NY: Addison Wesley Longman.

Eurydice. (2006a). Content and Language Integrated Learning (CLIL) at school in Europe. Brussels, Belgium: European Commission.

Eurydice. (2006b). Europeans and their languages. Special Eurobarometer 243. Brussels, Belgium: European Commission. Gardner, R.C., and P.F. Tremblay 1998. Specificity of affective variables and the Trait/State conceptualization of motivation in second language acquisition. In Social psychological perspectives on second language learning, ed. R. Agnihotri, A.L. Khanna, and I. Sachdev, 3152. New Delhi: Sage.

Eyres, I. (2004). Primary English. London: Paul Chapman Publishing.

Gass, S and Selinker, L. (2001). Second Language Acquisition: An Introductory Course. Mahwah. NJ: Erlbaum.

Gultom, E. (2016). Assessment and Evaluation in EFL Teaching and Learning. ISELT-4.

Harrel, K. (2005). Attitude is Everything: 10 Life Changing Steps to Turn attitude into action. Revised Edition. New York: Harper Business.

Kara, A. (2009). The effect of a 'learning theories' unit on students' attitudes towards learning. Australian Journal of Teacher Education, 22, 205-211.

Karahan, F. (2007). Language attitudes of Turkish students towards the English language and its use in Turkish context. Journal of Arts and Sciences, 7, 73-87.

Marsh, D. (2008). Language awareness and CLIL. In Encyclopedia of language and education. Knowledge about language, 2nd ed., vol. 6, ed. J. Cenoz and N.H. Hornberger, 23-46. New York: Springer ScienceBusiness Media LLC.

Tanjak: Jounal of Education and Teaching, Vol. 2, No. 1, 2021 http://ejournal.stainkepri.ac.id/index.php/tanjak 
Masgoret, A. M., and Gardner, R. C. (2003). Attitudes, motivation, and second language learning: A meta-analysis of studies conducted by Gardner and associates. Language Learning 53, no. 1: 23-63.

Mensah, J., Okyere, M., and Kuranchie, A. (2013). Student attitude towards mathematic and performance: does the teacher attitude matter? Journal of Education and Practice,3, 132-139.

Mustafa, H.H., Rashid, M.A., Atmowardoyo, H., and Dollah, S. (2015). Students' attitudinal factors in learning English as a foreign language. Journal of Language Teaching and Research,6, 1187-1194.

Ruiz de Zarobe, Y., and D. Lasagabaster. (2010). CLIL in a bilingual community: The Basque Autonomous Community. In CLIL in Spain: Implementation, results and teacher training, ed. D. Lasagabaster and Y. Ruiz de Zarobe, 12-29. Newcastle, UK: Cambridge Scholars.

Saidat, A, M. (2010). Language attitude: the case of Jordan. International Journal of Academic Research, 2, $235-243$.

Seikkula, L. J. (2007). CLIL learning: Achievement levels and affective factors. Language and Education 21, no. 4: 32-41.

Shams, M. (2008). Students' attitude, motivation, an anxiety towards English learning. Journal of research and reflection in education, 2, 121-144.

Yara, P.O. (2009). Relationship between teachers' attitude and students' academic achievement in mathematic in some selected Senior Secondary Schools in South0western Nigeria. European Journal of Social Science,3, 364-369.

Tanjak: Jounal of Education and Teaching, Vol. 2, No. 1, 2021 http://ejournal.stainkepri.ac.id/index.php/tanjak 